\title{
Krzysztof Jasiewicz
}

Instytut Studiów Politycznych PAN

\section{Obława Augustowska - stan badań, ich uwarunkowania i perspektywy}

Zarys treści: Tekst stanowi autorską próbę oceny wiedzy historycznej na temat Obławy Augustowskiej, a także polemikę z ustaleniami innych historyków oraz działaniami Białostockiego Oddziału IPN.

Outline of content: The text is an original attempt by the author to evaluate the historical knowledge on the Augustów Roundup, as well as a polemics with the findings of other historians and the activities of the Białystok Branch of the Institute of National Remembrance (IPN).

Słowa kluczowe: obława augustowska, zbrodnie sowieckie w Polsce, polityka sowiecka na wyzwalanych ziemiach Polski, II wojna światowa, antykomunistyczny ruch oporu w Polsce

Keywords: Augustów Roundup, Soviet atrocities in Poland, Soviet politics in the liberated Polish lands, Second World War, anti-communist resistance in Poland

Tekst niniejszy nie jest stricte naukowym artykułem, lecz bardziej moją relacją, względnie formą mieszaną. Wyjaśniam to i podaję szczegóły w dalszej jego części. Chociaż prezentuję nieznane dokumenty pochodzące $\mathrm{z}$ archiwum FSB, a także niedawno pozyskaną - i siłą rzeczy także nieznaną - relację z przebiegu Obławy Augustowskiej na Grodzieńszczyźnie od miejscowego świadka. Proszę pamiętać, iż każda relacja - również moja - jest subiektywna, taka jest jej natura.

Truizmem jest stwierdzenie, że droga do prawdy o Obławie Augustowskiej wiedzie przez postsowieckie archiwa, głównie moskiewskie i białoruskie, oraz prace archeologiczno-poszukiwawcze. Problemem są także interpretacje istniejących i znanych nam dokumentów lub faktów. Jak się wydaje, warto w tej sytuacji sięgnąć do metodyki i metodologii badań katyńskich, czyli układania puzzli, co się nieźle sprawdziło. Przecież zanim otrzymaliśmy dokumenty archiwalne trzymane w największej tajemnicy przed oczyma postronnych, to z grubsza wiedzieliśmy, co się stało w Katyniu, kto za tym stoi itd. Archiwalia w dużej mierze jedynie nasz 
stan wiedzy doprecyzowały i uwiarygodniły ${ }^{1}$. Czynnikiem mającym ogromne znaczenie dla badań nad Obławą Augustowską jest ogólny bezwład i desintéressement władz polskich ${ }^{2}$ oraz wadliwe od samego początku działania Instytutu Pamięci Narodowej, zwłaszcza Białostockiego Oddziału IPN, przede wszystkim zaś jego pionu prokuratorskiego ${ }^{3}$.

Śledztwo - ze względu na możliwość powiązań środowiska białostockiego z byłymi funkcjonariuszami UB i MO z Białegostoku i innych miast województwa białostockiego, którzy wraz z sowieckimi siłami wojskowo-policyjnymi uczestniczyli w Obławie Augustowskiej, czy funkcjonariuszami SB w okresie późniejszym, którzy usiłowali infiltrować wszelkie inicjatywy zmierzające do ustalenia losów zaginionych - od początku skazane zostało na porażkę przez wadliwe usytuowanie. Śledztwa tego typu, gdzie istnieje ryzyko utrudniania i mataczenia przez osoby miejscowe, od razu należy zlecać odległym placówkom.

Jak to śledztwo wyglądało w praktyce, mogę zaświadczyć osobiście. I tak matka mojego kolegi zamieszkała w Płocicznie (osada na skraju Puszczy Augustowskiej ok. $10 \mathrm{~km}$ na południowy wschód od Suwałk) została powiadomiona przez prokuratora, że zostanie przesłuchana na tę okoliczność w miejscu zamieszkania. Przybyły prokurator uzyskał informację, że świadek niczego nie wie, a o Obławie dowiedział się niedawno z lokalnej prasy. Drugi przypadek dotyczył mojej osoby. Zostałem zawezwany do złożenia zeznań w sprawie jak wyżej i chociaż poinformowałem prowadzącego śledztwo, iż urodziłem się po tej zbrodni i nic osobiście nie widziałem, to $z$ uporem nalegał na moje stawiennictwo. Przypuszczam, że wszystko to było robione dla statystyki i stworzenia pozorów pracy. Zeznań przybywało, półka pęczniała, wiedzy o zdarzeniu z pewnością nie przybyło, a trochę publicznych pieniędzy ubyło.

Kwestii badawczych, a nawet formalnych (nazewnictwo) nie udało się rozstrzygnąć do dzisiaj. Instytucje i osoby, które prezentowały odmienne stanowisko

${ }^{1} \mathrm{O}$ tej metodyce i metodologii zob. szerzej: K. Jasiewicz, Rola teorii, hipotez i spekulacji w wyjaśnianiu zbrodni katyńskiej. Rzecz o metodologii i metodyce badań, „Przegląd Historyczno-Wojskowy” 13(64) (2012), nr 4 (242). Archiwalia katyńskie zob. fundamentalne dzieło polskich i rosyjskich historyków i archiwistów: Katyń. Dokumenty zbrodni, red. i oprac. nauk. W. Materski, N. Lebiediewa i in., t. 1: Jeńcy nie wypowiedzianej wojny, Warszawa 1995; t. 2: Zagłada, Warszawa 1998; t. 3: Losy ocalatych, Warszawa 2001; t. 4: Echa Katynia, Warszawa 2006.

${ }^{2}$ Chodzi o akcję zbierania podpisów pod petycją do Władz Państwa Polskiego o ustalenie miejsc spoczynku Ofiar Obławy Augustowskiej i wyjaśnienia wszystkich okoliczności tej zbrodni. Zebrano ponad 15 tys. podpisów i przekazano kopie list do Rządu, Prezydenta, Sejmu, Senatu i MSZ; instytucje te na apel nie zareagowały. Na mocy ustawy z 9 lipca 2015 r. ustanowiono dzień 12 lipca „Dniem Pamięci Ofiar Obławy Augustowskiej 1945 roku” (Dz.U. 2015, poz. 1181), tyle że władze nie organizują żadnych obchodów.

${ }^{3}$ Mowa tu o okresie od powstania IPN do 2015 r., który pokrywa się z okresami kierownictwa Białostockiego Oddziału IPN w osobach Cezarego Kukli i Barbary Bojaryn-Kazberuk; od 2015 r. kieruje nim osoba spoza Białegostoku i Podlasia - dr hab. Piotr Kardela. Zob. też o tym - relacja ks. prałata Stanisława Wysockiego, prezesa Związku Pamięci Ofiar Obławy Augustowskiej (ZPOOA) oraz liczne pisma w Archiwum ZPOOA. 
od Białostockiego Oddziału IPN i sprzeciwiały się monopolizacji tematu przez tę instytucję, były eliminowane w sposób uwłaczający kulturze dyskursu naukowego. I tak jeden z oponentów IPN został „uderzony” zachowaną własną teczką w archiwum tegoż (białostockiego) IPN. Nic z niej nie wynikało, a na pewno nie w świetle obowiązujących regulacji prawnych - że był tajnym współpracownikiem SB. Ale ta informacja wypłynęła na zewnątrz, jeszcze wtedy, gdy dostęp do archiwaliów nie był prosty.

$\mathrm{Na}$ okrągłą 70. rocznicę zbrodni w Augustowie przygotowano premierę filmu dokumentalnego „Obława” w reżyserii Beaty Hyży-Czołpińskiej. Narracja filmu została oparta na nieprofesjonalnej „wiedzy” warszawskiej dziennikarki Alicji Maciejowskiej, członkini, powstałego 2 sierpnia 1987 r. w Suwałkach, Obywatelskiego Komitetu Poszukiwań Mieszkańców Suwalszczyzny Zaginionych w Lipcu 1945 r. Dziś osoba ta nie żyje, więc poza niekompetencją nie postawię jej żadnego zarzutu. Miałem okazję osobiście wysłuchać jej wypowiedzi 14 października 2011 r. w Domu Spotkań z Historią w Warszawie. Prowadziłem tam spotkanie z dr. Nikitą Pietrowem, wiceprzewodniczącym Stowarzyszenia „Memoriał” w Moskwie, prezentując jego ogromny dorobek w zakresie badań nad sowieckim aparatem bezpieczeństwa i jego zbrodniami, w tym nad Obławą Augustowską. Na sali była Maciejowska w towarzystwie kilku osób, b. członków owego Obywatelskiego Komitetu. Stwierdziła, że wszelkie spekulacje na temat liczby ofiar Obławy są nieuprawnione, gdyż oni sami sprawę „zbadali” gruntownie, sporządzili listę zaginionych. Spenetrowali cały teren objęty Obławą, ustalili, że odbywała się ona tylko po polskiej stronie i że w tej sprawie dyskusja jest bezprzedmiotowa.

Kilka lat później w wydawnictwie IPN „Pamięć.pl” wypłynęła informacja, że jedna z bardzo aktywnie uczestniczących w pracach Komitetu osób, Paweł Mikłasz, szef podziemnego wydawnictwa „Myśl” w Warszawie, który też finansował prace przy zbieraniu relacji w terenie, okazał się tajnym współpracownikiem SB. W „badaniach” pomagali jego czterej pracownicy zatrudnieni w wydawnictwie „Myśl” Anny Pyżewskiej, że: „[...] mimo jego podwójnej roli żaden członek komitetu [tak w oryginale; winno być z dużej litery] nigdy nie został aresztowany, nie skonfiskowano też zebranych materiałów"s.

Można ten fakt zinterpretować zupełnie inaczej. Wszak to jedna $\mathrm{z}$ najbardziej znanych technik stosowanych w służbach specjalnych, zwłaszcza popularna w sowieckich i w szkolonych przez ich doradców służbach tzw. państw socjalistycznych. Polega na stworzeniu organizacji/instytucji itp. pod własną kontrolą, jedynie w celu przyciągnięcia najaktywniejszych w danej sprawie elementów, przy jednoczesnym uważnym przyglądaniu się celom i działalności śledzonej grupy.

\footnotetext{
4 A. Pyżewska, Komitet niosący nadzieję, w: Obława Augustowska (dod. do „Pamięć.pl”), [Warszawa, lipiec 2015], s. 25.

${ }^{5}$ Ibidem.
} 
Maciejowska et consortes odwiedzili sto kilkadziesiąt miejscowości, przeprowadzili kilkaset rozmów i zebrali dane o 370 zaginionych osobach. Należy dodać, że korzystali także obficie z dorobku kilku rad narodowych, które sporządzały zaraz po Obławie swoje listy zaginionych, czym się specjalnie nie pochwalili. Komitet zakończył działalność przekazaniem zebranego materiału do Prokuratury Wojewódzkiej w Suwałkach na początku 1992 r., a ta 27 lutego wszczęła śledztwo, zawieszone z braku postępów 5 listopada 1992 r. Po powstaniu IPN dokumentacja ta trafiła do Oddziału IPN w Białymstoku, który śledztwo wznowił i prowadzi je do chwili obecnej, raczej bez powodzenia 6 .

Interesujące, że jeden z założycieli Obywatelskiego Komitetu Poszukiwań, Stanisław Kowalczyk, pracownik Wytwórni Podkładów Strunobetonowych „Kolbet” w Suwałkach, w którego mieszkaniu utworzono właśnie ów Komitet, w dalszej pracy był izolowany. Gdy przyjeżdżali członkowie warszawscy czy ich goście, proszono go, by w posiedzeniach nie brał udziału. Bardziej dosadnie - był wypraszany za drzwi. Było mu przykro i nie rozumiał tego, lecz nie protestował. Opowiedział o tym ks. prałatowi Stanisławowi Wysockiemu, który uważał Kowalczyka za człowieka „prawego, wielkiego serca i uczciwości”"

Może warto dokładnie przyjrzeć się wszystkim członkom Obywatelskiego Komitetu Poszukiwań Mieszkańców Suwalszczyzny Zaginionych w Lipcu 1945 r. oraz osobom współdziałającym pod kątem współpracy bądź jej braku z SB, czy w ogóle pod kątem istniejących jakichkolwiek dokumentów (bądź ich braku)na ich temat $\mathrm{w}$ dokumentacji b. SB? Podobnie warto pod tym kątem oraz ewentualnych powiązań rodzinno-towarzyskich z rodzinami b. uczestników i współpracowników sowieckich w Obławie sprawdzić poprzednie kierownictwa i prokuratorów Białostockiego Oddziału IPN oraz osoby z centrali, które z tymi sprawami miały coś wspólnego. Jak to zrobić? Dokładnie tak, jak w procedurach lustracyjnych, a wyłowienia powiązań rodzinno-towarzyskich, ewentualnie „resortowych” korzeni, dokonać poprzez media. Znajdą się tacy, co wskażą trop, resztę załatwia się rutynowo. Jest to konieczne dla rozwiania pojawiających się wątpliwości co do rzetelności badań i śledztwa w sprawie Obławy Augustowskiej.

Już film dokumentalny Beaty Hyży-Czołpińskiej „Obława” (2015), zrobiony na zamówienie IPN - Oddział Białystok, podważył wiarygodność „badan'” Komitetu, gdyż zaprezentowano w nim relacje mieszkańców wsi Kalety, leżącej po stronie białoruskiej, z których wynikało, że w tej wsi aresztowano parę osób i że był tam obiekt (stodoła), pełniący funkcję obozu filtracyjnego. Był też przypuszczalnie miejscem, w którym przetrzymywano dużą grupę zatrzymanych $\mathrm{z}$ okolicy lub z terenów polskich. Osoby te później pędzono drogą w stronę granicy polskiej, zapewne do miejsca egzekucji. Należy dodać, iż film ten obnaża, ujmując

\footnotetext{
${ }^{6}$ J.J. Milewski, Zaginieni w obławie augustowskiej - poszukiwania i pamięć, w: Obława Augustowska (lipiec 1945 r.), red. J.J. Milewski, A. Pyżewska, Białystok 2005, s. 78, 82-83.

7 Relacja ks. prałata Stanisława Wysockiego.
} 
najoględniej, słabe przygotowanie naukowe pracowników białostockiego IPN, dla którego - z niewiadomych powodów - Alicja Maciejowska stała się „guru”. I tak np. w jednym z ujęć widzimy świadków, którzy twierdzą, iż widzieli, jak ich ojciec pomachał im z odjeżdżającego „czarnego worona” (więźniarka służąca do przewozu osób zatrzymanych). Jest to niemożliwe, ponieważ samochód ten ma w środku małe celki, w których zamyka się więźniów, a okienko z tyłu daje dzienne światło dla siedzącego/siedzących na końcu pojazdu wartownika/ wartowników, funkcjonariuszy NKWD ${ }^{8}$. Takich wpadek jest więcej. Mamy w filmie niedorzeczny komentarz Maciejowskiej, mamy też błyskotliwe uwagi prokuratora prowadzącego śledztwo, zabiera głos główny ekspert białostockiego IPN - Jan Jerzy Milewski. Wszyscy w tym samym groteskowo-operetkowym stylu?. Również na tej samej konferencji w Augustowie, podczas której pokazano ów feralny film, były referaty, opracowane w oparciu o nieznane wcześniej IPN-owi dokumenty sowieckiej proweniencji o Obławie Augustowskiej. Dokumenty pojawiły się dużo wcześniej na stronie internetowej Ministerstwa Obrony Federacji Rosyjskiej jako materiały dotyczące udziału Armii Czerwonej w II wojnie światowej (wedle ich terminologii - Wielkiej Wojnie Ojczyźnianej) ${ }^{10}$. Tymczasem Oddział IPN Białystok informował opinię publiczną, że takowe dokumenty pozyskał, co rażąco rozmijało się ze stanem faktycznym. Bo ich nie pozyskał, lecz przeczytał i to pewnie jako ostatni. Z dokumentów sowieckich wynika jednoznacznie, że powierzchnia przeczesywana przez wojska sowieckie była większa od „ustalonej” przez Maciejowską i Obywatelski Komitet Poszukiwań Mieszkańców Suwalszczyzny Zaginionych w Lipcu 1945 r. i obejmowała obszary leżące w lipcu 1945 r. poza granicami Polski ${ }^{11}$.

Jeden znamienny szczegół. Prawie wszystkie rodziny, które utraciły bliskich w Obławie zrzeszone są w stowarzyszeniu o nazwie „Związek Pamięci Ofiar Obławy Augustowskiej" (ZPOOA), które jest jedyną organizacją skupiającą rodziny Ofiar. Ani w filmie, ani w wydawnictwach z okazji 70., okrągłej rocznicy tej zbrodni nie ma nawet wzmianki o istnieniu tej struktury, bardzo zresztą aktywnej w promocji sprawy i innych działaniach patriotycznych. Jak sądzę, była to kara za „samowolne” zorganizowanie ogólnopolskich, międzynarodowych obchodów 69. rocznicy Obławy w Warszawie. Organizatorami były ZPOOA, Instytut Studiów Politycznych PAN, Uniwersytet Kardynała Stefana Wyszyńskiego i rosyjski „Memoriał”. Białostocki IPN został też zaproszony, ówczesna dyrektor zasiadła jako pełnoprawna przedstawicielka IPN za stołem prezydialnym. Miała najdłuższe wystąpienie. Podobnie

8 Zazwyczaj dwóch w mniejszym 6-osobowym samochodzie, bo były też „czarne worony” o pojemności autobusowej, do przewozu 30 aresztantów. Cele przylegają do ścian bocznych pojazdu, równolegle do osi jezdni/drogi.

9 Zob. film „Obława”, reż. Beata Hyży-Czołpińska.

10 https://pamyat-naroda.ru (dostęp: 3.10.2018).

11 Zob. referaty z tej sesji i podawane tam podstawy wyjściowe jednostek 50 Armii 3 Frontu Białoruskiego przed rozpoczęciem Obławy Augustowskiej. 
prokurator Kulikowski prowadzący śledztwo. Lecz - jak widać - pomysł się nie spodobał i odebrano to widocznie jako działalność wrogą i konkurencyjną. No i bez ich błogosławieństwa.

Gwoli jasności, piszący te słowa też jest w pewnym sensie stroną w tym sporze i identyfikuje się ze stanowiskiem i działaniami Związku Pamięci Ofiar Obławy Augustowskiej. Jest także powiązany rodzinnie i więzami przyjacielskimi z ks. prałatem Stanisławem Wysockim, prezesem ZPOOA. Jest także członkiem ZPOOA i jego naukowym konsultantem. Jestem z tego dumny i traktuję to jako szczególny zaszczyt, ale rodzi się z tego oczywista implikacja metodologiczno-etyczna. Że mój tekst jest i artykułem naukowym, i - w pewnym sensie - relacją świadka (raczej bardziej świadka wydarzeń), bo chociaż Obława Augustowska miała miejsce przed moim przyjściem na świat, to jednak była ona obecna w moim życiu od samego początku. Mówiło się o tym w domu i w rodzinie odkąd sięga moja pamięć. Proszę brać to pod uwagę. Przedstawiam własną, subiektywną ocenę wydarzeń, aczkolwiek starałem się zawsze być ponad podziałami. Nawet raz próbowałem pogodzić strony jako mediator, ale strona IPN-owska mnie - delikatnie mówiąc - oszukała i wykorzystała do swojej gry. Również jako historyk zajmujący się problematyką wschodnią, począwszy od 1991 r. jeździłem na kwerendy archiwalne do krajów b. ZSRS i tam, w miarę swoich możliwości, próbowałem szukać dokumentów dotyczących tej zbrodni (bez powodzenia) ${ }^{12}$. O zaginięciach na Suwalszczyźnie napisałem w 1997 r. w swojej książce Zagłada polskich Kresów - pierwszej polskiej ex aequo z książką Albina Głowackiego ${ }^{13}$ monografii opartej na bogatych źródłach sowieckich, nazywając wydarzenie dziś zwane Obławą Augustowską „operacją katyńską numer trzy” (nie wchodząc w szczegóły, bo ten tekst jest o czymś innym - pierwsza, to ta właściwa operacja katyńska z wiosny 1940 r., drugą operacją katyńską nazwałem mordy na przetrzymywanych w więzieniach na Kresach Wschodnich w czerwcu 1941 r.; zainteresowanych odsyłam do mojej książki). Pisałem: „Najbardziej interesujący aspekt drugiej okupacji [sowieckiej, tj. okres 1944-1945, czyli od wkroczenia wojsk sowieckich na ziemie wschodnie II RP do konferencji poczdamskiej], to prawdopodobnie zrealizowanie na Kresach kolejnej operacji typu «katyńska», którą roboczo nazwiemy operacją katyńską numer trzy [...]. Hipotezę tę uprawdopodobniają znane skutki aresztowań z poprzedniego okresu [tj. pierwszej okupacji sowieckiej 1939-1941], a także zaginięcia na Suwalszczyźnie (pisała o nich prasa w latach osiemdziesiątych). W słynnej dziś obławie z lata 1945 r. NKWD aresztowała ok. tysiąca osób, na ogół związanych z AK, po których odtąd wszelki słuch zaginął. Odkrycie grobów katyńskich być może nie zniechęciło ZSRR do kontynuowania ludobójczych praktyk, a zaginięcia

${ }^{12}$ W Archiwum ZPOOA znajduje się dokument z 1992 r. potwierdzający moje poszukiwania na terenie ZSRR.

13 A. Głowacki, Sowieci wobec Polaków na ziemiach wschodnich II Rzeczypospolitej 1939-1941, wyd. 1: Łódź 1997, wyd. 2: Łódź 1998. 
na Suwalszczyźnie i Kresach mogły stanowić tę samą operację"14. Hipoteza ta („zaginięcia na Suwalszczyźnie i Kresach [w latach 1944-1945] mogły stanowić tę samą operację"), jak się wydaje, znajduje potwierdzenie w doskonale udokumentowanych i bardzo profesjonalnych badaniach Grzegorza Motyki ${ }^{15}$, o których piszę w dalszej części artykułu/relacji. Wszystko więc wymaga ponownego namysłu, uporządkowania i reinterpretacji.

Zacznijmy od nazwy, którą jednak pisałbym, ze względu i na szacunek, i zasady polskiej pisowni (nazwa własna) z dużych liter (to się zresztą odnosi do wszystkich tego typu tragicznych czy heroicznych wydarzeń, jak powstania, czy wielkie zbrodnie, jak np. Zbrodnia Katyńska). A więc powinniśmy pisać Obława Augustowska, a nie obława augustowska, co zdarza się nagminnie. Ta nazwa pojawia się gdzieś dopiero w latach dziewięćdziesiątych, może jeszcze później. Dodajmy od razu, że ma ona związek lingwinistyczny z Puszczą Augustowską, a nie z miastem Augustów. Nie jest znany jej autor, choć jeden z byłych pracowników IPN w Białymstoku, wspomniany J.J. Milewski, sobie przypisuje jej wymyślenie. Nie przedstawił on jednakże żadnego dowodu, a dowodem w takiej sprawie może być tylko przypis wskazujący, gdzie i kiedy użył tego sformułowania.

Historycznie ujmując - opieram się na własnej pamięci i przenoszonej w niej pamięci rodzinnej - w momencie prowadzenia samej operacji nie istniał żaden termin ją opisujący ani nikt nie określał jej masowego zakresu, lecz ogólnie mówiło się najczęściej, że kogoś aresztowano (czasami padało nazwisko), lub bardziej ogólnie, że „Ruscy”, „Sowieci”, względnie „NKWD” prowadzi (lub prowadziło) aresztowania $\mathrm{w}$ takiej czy innej miejscowości lub na takim lub innym terenie, czy kogoś w ogóle aresztowało. Przez lata była to tajemnica rodzin Ofiar, z którą się nikt nie obnosił' ${ }^{16}$.

Dopiero po pewnym czasie - trudno to w tej chwili oszacować, myślę, że co najmniej po kilku-kilkunastu miesiącach lub może nawet latach - pojawia się nazwa „obława”, raczej rozumiana jako określenie typu operacji wojskowo-policyjnej (rodzaju „kotła”), niż nazwa własna, do której wkrótce dołącza określenie czasowe - „lipcowa”. I też na początku wydaje się, że znaczenie terminu „obława lipcowa” niewiele różniło się od terminu „obława”. Z czasem pojęcie stało się nazwą własną, co wcale nie oznacza, że stosowano reguły pisowni. Nazwa Obława

${ }^{14}$ K. Jasiewicz, Zagłada polskich Kresów. Ziemiaństwo polskie na Kresach Pótnocno-Wschodnich Rzeczypospolitej pod okupacją sowiecka 1939-1941, wyd. 1: Warszawa 1997, wyd. 2: Warszawa 1998, s. $269-270$.

15 G. Motyka, Na białych Polaków obława. Wojska NKWD w walce $z$ polskim podziemiem 1944-1953, Kraków 2014, passim.

16 Informacje własne zaczerpnięte z wiedzy moich nieżyjących Rodziców oraz mojej własnej pamięci. Jako ciekawostkę mogę podać fakt, iż w moim najbliższym otoczeniu (w Suwałkach na mojej ulicy i sąsiednich) aresztowano kilka osób, których rodziny dobrze znałem, a o tym fakcie dowiedziałem się dopiero, studiując różne listy zaginionych, pojawiające się wiele lat po tej zbrodni. I nawet wtedy moi rozmówcy nie kwapili się do opowieści, jak było. To właśnie objaw paraliżującego strachu po traumatycznych przejściach. 
Augustowska ma chyba bardzo krótki rodowód. Powszechnie zaczęto ją stosować gdzieś od przełomu wieków XX i XXI, przy czym zważywszy na pewną rywalizację pomiędzy Suwałkami a Augustowem (czy duże ambicje różnych osób), pojawiały się efemerydy w rodzaju „Obława Augustowsko-Suwalska” lub „Obława Augustowska na Suwalszczyźnie”. Na szczęście mamy to za sobą.

W najbardziej podstawowej literaturze przedmiotu termin „Obława Augustowska” (pisany z małych liter) pojawia się (chyba że coś przegapiłem) dopiero w 2003 r. $^{17}$ Wspomniany J.J. Milewski występuje w 2005 r. z Obławą $\mathrm{w}$ tytule, pisaną z małych liter, co już jego roszczenia dość ogranicza, w gronie trzech autorów, którzy posługują się też Obławą jako hasłem rzeczowym, a nie nazwą własną ${ }^{18}$. W swoim dość ciekawym artykule J.J. Milewski obok tytułu w tekście używa w charakterze hasła rzeczowego „obława augustowska” jeszcze 3 razy, terminu/hasła rzeczowego „obława lipcowa” - 5 razy, natomiast określenia „obława” aż 23 razy. Wnioski pozostawiam Czytelnikowi.

Fakt, że w Obławie główną rolę odgrywał sowiecki kontrwywiad wojskowy SMIERSZ i nawet jego nazwę poznaliśmy dopiero w połowie lat dziewięćdziesiątych z pisma rosyjskiej Głównej Prokuratury Wojskowej. Od tego momentu wiemy, że to kontrwywiad zajmował się aresztowaniami. Wojsko, wszystko na to wskazuje - tylko wielkim przeczesywaniem lasów i wsi ${ }^{19}$.

Nie jestem pewien, czy informacja z pisma rosyjskiej Głównej Prokuratury Wojskowej była ścisła, bowiem z relacji rodzinnej dotyczącej aresztowania Ludwika Wysockiego i jego córek Anieli i Kazimiery w dniu 27 lipca 1945 r. w Białej Wodzie nie bardzo to wynika. Przyjechało ich kilkunastu z polskim przewodnikiem po Ofiary. Nie skuli ani nie związali im rąk, co wydaje się być nieprofesjonalne. Minęło 8 dni od oficjalnego zakończenia Obławy, więc raczej to był SMIERSZ, bo to, że mieli normalne wojskowe mundury, niczego nie dowodzi. Kontrwywiad ten właśnie ich używał, miał identyczne pagony ze stopniami jak Armia Czerwona i był tajny. Nikt nie wiedział, kto jest lub nie jest w SMIERSZ-u. Profesjonalny był jednak podjazd pod zabudowania. Ciężarówka podjechała tyłem, co w wypadku ataku ułatwiało ucieczkę oprawcom na wąskiej drodze biegnącej doliną, gdzie trudno było szybko zawrócić ${ }^{20}$.

Przyjmowało się przez wiele lat, że Obława Augustowska miała miejsce w powiatach suwalskim, augustowskim, sokólskim i byłym powiecie sejneńskim. Tak teren Obławy pojmowała Maciejowska i tak określony teren kanoniczny obowiązywał do współczesności, czemu i dziś dają wyraz tablice w kościołach w stolicach powiatów, ufundowane i odsłonięte $\mathrm{z}$ honorami przez ZPOOA z udziałem

17 M. Filipowicz, Obława augustowska w lipcu 1945 r. w świetle zachowanych dokumentów, „Rocznik Augustowsko-Suwalski" 3 (2003).

18 Zob. „Spis treści”, w: Obława augustowska (lipiec 1945 r.).

19 J.J. Milewski, op. cit., s. 71-85.

20 Relacja ks. prałata Stanisława Wysockiego; zob. V.J. Birstein, SMIERSZ. Tajna broń Stalina. Sowiecki kontrwywiad wojskowy podczas II wojny światowej, Warszawa 2013, passim. 
władz państwowych i kościelnych. Są one kopiami tablicy z inskrypcją o Obławie Augustowskiej, umieszczonej przez ZPOOA na Jasnej Górze. Znajdują się one w konkatedrze p.w. św. Aleksandra w Suwałkach, w Bazylice p.w. Najświętszego Serca Pana Jezusa w Augustowie, w kościele p.w. św. Antoniego Padewskiego w Sokółce i w Bazylice p.w. Najświętszej Maryi Panny w Sejnach ${ }^{21}$.

Tymczasem śledząc działania wydzielonej kompanii fizylierów z 1 Praskiego Pułku Piechoty pod dowództwem porucznika Maksymiliana Sznepfa, która brała udział w Obławie Augustowskiej, widzimy, że dokonywała ona aresztowań w innych terminach i na innych obszarach, niż się dotąd przyjmowało. To zmienia naszą perspektywę czasowo-przestrzenną i każe inaczej spojrzeć na samą operację. W okresie 23 lipca - 8 sierpnia 1945 r. kompania Sznepfa złapała 67 „bandytów” w okolicach Siemiatycz i do końca sierpnia poszukiwała ich w Knyszynie i okolicy. W okresie 24-29 lipca 1945 r. przeszukiwała Boćki i Czarną Wieś w powiecie sokólskim, wieś Granne nad Bugiem - 30 lipca. A wcześniej - w czerwcu 1945 r. miasteczko Drohiczyn i okoliczne wsie $e^{22}$. Wynika zatem, że być może Obława rozwinęła się wzdłuż wschodniej granicy na południe daleko poza Białystok, gdzieś do linii rzeki Bug.

Zupełnie nowym dokumentem, który także obala teorie Maciejowskiej, jest zdobyta przez ZPOOA relacja od mieszkańca wsi Kadysz w obwodzie grodzieńskim, leżącej przy starej drodze z Sopoćkin do Kopciowa (to już Republika Litewska), na północ od Sopoćkin, $4 \mathrm{~km}$ od granicy nad rzeką Czarna Hańcza (do ustalenia granicy w 1946 r. wieś leżała w woj. białostockim, pow. augustowski, gm. Wołłowiczowce) ${ }^{23}$. Okazuje się ponad wszelką wątpliwość, że w tamtych stronach prowadzono też operację przeczesywania lasów i wsi. Niestety, relacja została sporządzona nieprofesjonalnie ${ }^{24}$; ze względu na bezpieczeństwo świadka i osoby nagrywającej nie podam ich nazwisk. „Szli tyralierą. Po lesie wszędzie przeszukiwali, po domach [...]. Sowietów było jak meszek, pełno"25. Zdaniem relacjonisty Sowieci nie mieli dokładnego rozpoznania, kto był w AK, a polska partyzantka w okolicznych lasach utrzymała się „dosyć długo” (niejasne, co kryje się pod tym określeniem).

Ponownego uważnego przeczytania wymaga najważniejszy, znany nam, dokument sowiecki dotyczący Obławy Augustowskiej. Jest to szyfrotelegram nr 25212 szefa Głównego Zarządu Kontrwywiadu (GUKR) SMIERSZ Ludowego Komisariatu Obrony ZSRS Wiktora Abakumowa do narkoma Ławrentija Berii z 21 lipca 1945 r. Czytamy w nim:

${ }^{21}$ Informacje własne $\mathrm{z}$ udziału w tych uroczystościach.

${ }^{22}$ Centralne Archiwum Wojskowe, sygn. III.2-234 bp.

${ }^{23}$ https:/pl.wikipedia.org./wiki/Kadysz_(rejon_grodzieński) (dostęp: 3.10.2018).

${ }^{24}$ Nagrywający świadka był nieprzygotowany do zbierania informacji, nie sprawdził sprzętu i duża część relacji została nienagrana, względnie nagrana niewyraźnie. Rozmowa była chaotyczna, świadek nie był właściwie indagowany.

${ }^{25}$ Relacja anonimowa z przebiegu Obławy Augustowskiej we wsi Kadysz na Grodzieńszczyźnie. 
Zgodnie z Waszą instrukcją rankiem 20 lipca wysłałem samolotem do Treuburga [ob. Olecko] generała majora Gorgonowa, zastępcę szefa GUKR SMIERSZ wraz z grupą kontrwywiadowców w celu przeprowadzenia likwidacji bandytów aresztowanych w Puszczy Augustowskiej [...]. Wojska 3 Frontu Białoruskiego od 12 do 19 lipca przeczesywały okoliczne lasy, zatrzymano 7049 osób. Po rewizji zwolniono 5115, pośród pozostałych 1934 zatrzymanych rozpoznano 844, w tym 252 Litwinów, którzy utrzymywali związki z bandyckimi ugrupowaniami na Litwie i dlatego zostali przekazani miejscowym organom NKWD-NKGB Litwy. Trwa sprawdzanie 1090 osób, z których 262 Litwinów z tych samych przyczyn przekazano organom NKWD-NKGB. W efekcie liczba aresztowanych na dzień 21 lipca b.r. to zaledwie 592 osoby, ponadto trwa sprawdzanie 828 osób. Bandytom aresztowanym w lasach i kryjówkach odebrano 11 moździerzy, 31 karabinów maszynowych, 123 pistolety maszynowe, inne karabiny i pistolety, granaty oraz dwie radiostacje [...]. Jeśli po takim meldunku, Towarzyszu, uznacie operację za konieczną, proponujemy następujący schemat likwidacji bandytów:

1. Zlikwidować wszystkich zidentyfikowanych bandytów w liczbie 592 osób. W tym celu zostanie wydzielona grupa operacyjna i batalion wojsk Zarządu SMIERSZ 3 Frontu Białoruskiego, sprawdzone w praktyce podczas szeregu akcji kontrwywiadowczych. Pracownicy operacyjni i żołnierze batalionu dostaną precyzyjne instrukcje co do trybu likwidacji bandytów.

2. W trakcie operacji zostaną podjęte niezbędne kroki, aby nie dopuścić do ucieczki któregokolwiek z bandytów. W tym celu oprócz udzielenia dokładnego instruktażu pracownikom operacyjnym i żołnierzom batalionu, rejony lasu, gdzie będzie prowadzona operacja, po wcześniejszym przeczesaniu zostaną okrążone.

3. Odpowiedzialność za przeprowadzenie likwidacji bandytów zostanie złożona na barki zastępcy szefa Głównego Zarządu Kontrwywiadu 3 Frontu Białoruskiego, generała lejtnanta Zielenina.

Towarzysze Gorgonow i Zielenin to dobrzy i doświadczeni czekiści, więc wykonają to zadanie.

Pozostałe 828 osób sprawdzimy w ciągu pięciu dni - wszystkich wykrytych pośród nich bandytów zlikwidujemy w ten sam sposób. Meldunek o liczbie wykrytych w tej grupie bandytów zostanie Wam wysłany.

Proszę o dalsze instrukcje. Abakumow ${ }^{26}$.

W szyfrogramie Abakumowa jest wiele ważnych informacji, niezwykle istotnych dla naszej analizy. Zacznijmy od liczb, bo one wywoływały - po obu stronach „barykady” - ogromne emocje. Zderzyły się tu dwie przeciwstawne tendencje. Strona Białostockiego Oddziału IPN liczbę Ofiar konsekwentnie pomniejszała, albo kierowana wytycznymi Maciejowskiej, albo wpływami „resortowych” i innych dzieci lub

${ }^{26}$ Центральный архив ФСБ (Centralne Archiwum FSB), ф. 4-ос, оп. 3, д. 24, k. 179-181; cyt. za N. Pietrow, Psy Stalina, Warszawa 2012, s. 224-225; przekład z rosyjskiego wydania pod zdecydowanie lepszym tytułem: Палачи. Они выполняли заказы Сталина, Москва 2011. Korzystałem $\mathrm{z}$ wersji rosyjskojęzycznej (z dedykacją Nikity, dobrze mi znanego prywatnie). Ten sam dokument i in. zob. Н.В. Петров, По сценарию Сталина: роль органов НКВД-МГБ СССР в советизации стран Центральной и Восточной Европьы. 1945-1953 г2., Москва 2011, s. 164-166 і 269-270 (z identyczną dedykacją). 
z innych powodów, uparcie, przy każdej nadarzającej się okazji, arbitralnie stwierdzała, że w Obławie Augustowskiej zamordowano 592 osoby ${ }^{27}$.

Tymczasem strona społeczna, czyli środowisko ZPOOA, reagowała na tę liczbę wręcz alergicznie, utrzymując konsekwentnie, w tym piszący te słowa, że owo wyliczenie jest nieprawidłową interpretacją wyżej cytowanego dokumentu. I utrzymywała, że liczba zamordowanych jest dużo wyższa, narzucając w swojej narracji (w której miałem udział), że mieliśmy do czynienia z „drugim Katyniem” względnie z „kolejnym Katyniem” (określenia „mały Katyń” i „podlaski Katyń” uważano za złośliwe, a osoby je używające w tym środowisku były objęte ostracyzmem). Muszę z przykrością stwierdzić, że ani pomniejszanie, ani powiększanie liczby Ofiar, w tym ostatnim przypadku - co zrozumiałe - także ich sakralizowanie czy wręcz wynoszenie na ołtarze nie służą tej sprawie. Nie da się dziejów Polski/świata podzielić - wzorem Żydów i Holocaustu - na erę przed i po Obławie Augustowskiej. Z mojego punktu widzenia każda śmierć jest tragedią i nie ma większego znaczenia, czy doliczymy się 592 Ofiar czy około 2 tysięcy. Każde ludobójstwo jest okrutne i skrajnie obrzydliwe, i każda Ofiara zasługuje na najwyższy nasz szacunek, bez względu na to, czy to 5 osób czy 5 tysięcy.

Spokojnie przyjrzyjmy się liczbom w szyfrogramie Abakumowa. Między 12 a 19 lipca 1945 r. zatrzymano 7049 osób. Po rewizji zwolniono 5115. Pozostało 1934 (7049-5115=1934). W grupie 1934 rozpoznano 844 „bandytów”, w tym 252 Litwinów, którzy utrzymywali związki z „bandyckimi” ugrupowaniami na Litwie (tu uwaga własna, to kwestia wymagająca zbadania, czy oni rzeczywiście byli Litwinami w sensie etnicznym, czy może także, przynajmniej po części, Polakami - obywatelami już sowieckiej Litwy, czyli np. uciekającymi stamtąd do centrum Polski partyzantami AK, a zostali przekazani właściwym terytorialnie organom NKWD-NKGB do dalszej obróbki). Sprawdzanie prowadzono w cyklu 5-dniowym (to też ważne w dalszych rozważaniach) i w dokumencie dotyczyło 1090 zatrzymanych (1934-844=1090), z których 262 Litwinów z powyższych powodów przekazano według przynależności terytorialnej litewskim organom NKWD-NKGB (1090-262=828). W ostatecznym rozrachunku na dzień 21 lipca 1945 r. liczba aresztowanych „bandytów” wyniosła 592 osoby $(844-252=592)$ i trwało po polskiej stronie sprawdzanie 828 osób $(1090-262=828)^{28}$.

W moim przekonaniu błąd IPN był oczywisty. Szyfrogram Abakumowa jest jedynie przedstawieniem stanu faktycznego po przeczesaniu lasów Puszczy Augustowskiej i opisem zamysłu przeprowadzenia zbrodni ludobójstwa. Ponieważ nikt z tych 592 osób nie pojawił się w świecie żywych (i nawet nie jesteśmy w stanie ich zidentyfikować w tych dużych liczbach wyżej analizowanych), to chyba przyjęcie tej liczby przez IPN można tłumaczyć tylko względami pozamerytorycznymi. ZPOOA i ja osobiście, także jako konsultant naukowy tegoż stowarzyszenia uważamy, że tylko

27 Zob. publikacje Białostockiego Oddziału IPN w okresie od jego początków do 2015 r. Żadna inna liczba nie była brana pod uwagę.

28 N. Pietrow, Psy Stalina, s. 224-225. 
dokument wykonawczy, zapowiadany przez Abakumowa w cytowanym szyfrogramie, z załącznikiem - listą zamordowanych, byłyby zaledwie pośrednim dowodem na popełnienie zbrodni. Precyzyjne określenie liczby zamordowanych możliwe będzie tylko wtedy, gdy zostaną wskazane „doły śmierci” i będzie je można dokładnie przebadać. Ponieważ nikt z wysłanych na Litwę, ani nikt z poddanych „sprawdzaniu" po stronie polskiej też nigdy nie pojawił się w świecie żywych, to w naszym przekonaniu należy owe liczby zsumować, co daje liczbę 1934 teoretycznie zamordowanych $(844+1090=1934)$.

Wedle opinii Nikity Pietrowa zamordowano co najmniej 575 osób lub nawet ponad tysiąc ${ }^{29}$. Wiemy także, że po 21 lipca $1945 \mathrm{r}$. miały miejsce liczne zatrzymania. Ponad 100 osób zostało aresztowanych po 19 lipca 1945 r., duża grupa w dniach 25-27 lipca (tu wspomniani Wysoccy) ${ }^{30}$, były też aresztowania w sierpniu (np. Maria Węgrzynowicz - Daniłowce, 18 sierpnia; Piotr Wasilewski - Wychodna, 12 sierpnia) i później (np. Władysław Bergolec - Tartaczysko, 6 listopada 1945; Zygmunt Zieziulewicz - Serski Las, 19 listopada) ${ }^{31}$. Oczywiście rodzi się pytanie, czy te późne aresztowania mają związek z Obławą. Trudno odpowiedzieć, może w wyniku łańcuchowej eksploracji wyławiano dalej jakichś kandydatów na „bandytów”. Chodzi mi o taki np. łańcuch: zatrzymany A po obróbce wskazuje B, ten po obróbce wskazuje $\mathrm{C}$ itd. Wtedy proces wyłapywania musi się wydłużyć, a zbędni $\mathrm{ABC}$ itd. mogą być sukcesywnie likwidowani.

Również dzięki umiejętnym zabiegom ZPOOA, którego członkowie zwrócili się w bardzo uprzejmych słowach (w odróżnieniu od buńczucznych słów urzędowych) z prośbą o pomoc do FSB, uzyskano kilkadziesiąt odpowiedzi o pojmanych w Obławie, które znajdują się w dokumentacji przechowywanej w archiwum na Łubiance. Z nich też wyłania się obraz i chronologia tych aresztowań, aczkolwiek dane te bywają skąpe i niekompletne i sporządzane według różnych schematów.

I tak np. Stanisław Nowalski z Krasnopola, ur. 1920, został zatrzymany w lesie podczas „obławy przeprowadzonej siłami 3 Białoruskiego Frontu w Lasach Augustowskich na terytorium Polski. Od tej pory o nim więcej nie było żadnych wiadomości”32.

29 Relacja Nikity Pietrowa - za podstawę do podania tej liczby przyjął, iż w archiwum FSB zachowało się 575 teczek dotyczących osób aresztowanych w operacji przeczesywania Puszczy Augustowskiej, potem w rozmowach prywatnych podniósł liczbę do tysiąca, uważając, iż doszły do tego osoby później aresztowane. Ta konstrukcja ma wadę metodologiczną. Trzeba byłoby komisyjnie to policzyć i nie wykluczałbym, że mogą istnieć jeszcze inne teczki mające związek z tą sprawą, względnie teczki tych, których przypisano do innych kategorii znanych nam z czasów pierwszej okupacji (tj. lat 1939-1941), jak: „element antysowiecki”, „wrieditieli”, SOE (socialno-opasnyj element = społecznie niebezpieczny element) itd., itp.

${ }^{30}$ Relacja ks. prałata Stanisława Wysockiego.

${ }^{31}$ Lista osób zatrzymanych w czerwcu $i$ lipcu 1945 r. przez funkcjonariuszy UBP $i$ oddziały Armii Czerwonej, w: Obława Augustowska lipiec 1945 r. Wybór źródeł, red. J.J. Milewski, A. Pyżewska, Białystok 2010, s. $153 \mathrm{nn}$.

32 Archiwum ZPOOA, kopia dokumentu pochodzącego z Archiwum FSB w Moskwie, brak sygnatury i innych danych identyfikujących. 
Z kolei o zaginionym Józefie Grabowskim, ur. 1899, z Filipowa, dowiadujemy się, że został aresztowany 20 lipca 1945 r. w miejscu zamieszkania. „W materiałach archiwalnych nie ma informacji o przedstawieniu zarzutów, osądzeniu, rehabilitacji i dalszych jego losach"33. Kolejny przypadek: Witold Mrożewski (faktycznie Mroziewicz), ur. 1910 - Krasnoborki (k. Sztabina), zatrzymany 17 lipca 1945 r. jako „podejrzany o przynależność do Armii Krajowej”. Dalej identyczna formułka kończąca się stwierdzeniem, że nie ma informacji o jego dalszych losach ${ }^{34}$. Kolejny schemat, aresztowania poza datami obławy. Ciekawy jest przypadek rodziny Wysockich, bo chyba mają oni podwójne akta/teczki na Łubiance. W pierwszym komplecie podana jest jako data aresztowania 27 lipca, ale tylko przy Anieli znajduje się wpis: „podejrzenie o przynależność do Armii Krajowej”, lecz brakuje informacji, że została „aresztowana w miejscu zamieszkania”; przy pozostałych (Ludwik i Kazimiera) nie ma „podejrzeń o przynależność”, ale jest zapis, że zostali „aresztowani w miejscu zamieszkania"35. Jak wspomniałem, akta Anieli i Kazimiery są podwójne. W drugiej wersji zmiana polega na innych sygnaturach oraz obie mają wpisane, że zostały aresztowane w miejscu zamieszkania, brakuje wpisu o „podejrzeniu o przynależność”. Trudno mi to wytłumaczyć, zwłaszcza że z rodzinnej relacji wynika dokładnie, iż polski przewodnik rozpoznał Anielę jako osobę przychodzącą do punktu kontaktowego AK w Suwałkach ${ }^{36}$.

Kolejny schemat, ale niepewny, bo może także wynikać z niedbalstwa w dokumentach. Co oznacza obecność lub brak stwierdzenia w dokumentacji o „zatrzymaniu w miejscu zamieszkania”. Może ci, co nie mają tej adnotacji, zostali schwytani w lesie? Czy to może jedynie taka maniera, że jednego dobrze opisali, a drugiego niedbale? Spójrzmy na przykłady: Stanisław Rapczyński - wieś Sumowo, ur. 1897, aresztowany 26 lipca 1945 r. „w miejscu zamieszkania”, ale bez „podejrzenia o przynależność". Czy został namierzony wcześniej jako potencjalny konspirator, ewentualnie jako „element antysocjalistyczny" ${ }^{37}$ ? Lub Jan Janik, ur. 1902 - z Jaziewa, tamże aresztowany 20 lipca $1945 \mathrm{r}$. i podejrzewany o przynależność do $\mathrm{AK}^{38}$. Czy oznacza to, że wcześniej został namierzony dokładniej, czy zwykły przypadek? Podobnie Ludwik Butkiewicz, ur. 1909, ze wsi Czarniewo, tamże aresztowany 21 lipca 1945 r., podejrzewany o przynależność do AK ${ }^{39}$. Podobnie też Jan Domiński, ur. 1923, z miasteczka Raczki, tamże aresztowany 26 lipca $1945 \mathrm{r}$. pod zarzutem przynależności do $\mathrm{AK}^{40}$.

\footnotetext{
33 Archiwum ZPOOA, kopia pisma FSB nr 10/A-G-1640 z 18 VI 2013 r.

34 Archiwum ZPOOA, kopia pisma FSB nr 10/A-S-1393 z 14 VI 2013 r.

35 Archiwum ZPOOA, kopia pisma FSB nr 10/A-W-1602 z 17 VI 2013 r.; nr 10/A-W-1573 z 14 VI 2013 r.; nr 10/A-W-1575 z 14 VI 2013 r.

36 Archiwum ZPOOA, kopia pisma FSB nr 10/A-A-1600 z 17 VI 2013 r. (dot. Anieli) i nr 10/A-A1601 z 16 VI 2013 r. (dot. Kazimiery).

37 Archiwum ZPOOA, kopia pisma FSB nr 10/A-S-1647 z 18 VI 2013 r.

38 Archiwum ZPOOA, kopia pisma FSB nr 10/A-Ja-1650 z 18 VI 2013 r.

39 Archiwum ZPOOA, kopia pisma FSB nr 10/A-S-1711 z 21 VI 2013 r.

40 Archiwum ZPOOA, kopia pisma FSB nr 10/A-S-1596 z 17 VI 2013 r.
} 
Materiały z FSB zawierają bardzo zróżnicowane daty aresztowań i nie ma przynajmniej w posiadanej przez ZPOOA dokumentacji - osób z zarzutem „przynależności”. Są tylko osoby „podejrzane o przynależność”. Może to nas prowadzić do konkluzji, że zabijano na zapas, po bolszewicku, zakładając, iż lepiej z powodu jednego czy kilku „winnych” zabić wszystkich wraz z „niewinnymi”. To - jak mnie się wydaje (oprócz zauważonej przez Pietrowa niewielkiej liczby osób do zabicia oraz towarzyszącego zakłopotania i rozczarowania: „Jeśli po takim meldunku, Towarzyszu, uznacie operację za konieczną" ${ }^{41}$ mogła być przyczyna, dla której zamordowano wszystkich będących po owym pięciodniowym śledztwie. Był też inny powód. Ci ludzie, których po tej filtracji zwolniono by do domów, za dużo widzieli i wiedzieli, a nawet ze strzępów informacji można coś wywnioskować.

Z prezentowanej partii posiadanych materiałów z FSB najwcześniej został aresztowany Stanisław Nowalski z Krasnopola, dokładnie w pierwszym dniu operacji 12 lipca 1945 r., w miejscu zamieszkania i bez podejrzeń o przynależność, najpóźniej zaś Bolesław Romanowski - z Berżnik, 28 lipca 1945 r., brak adnotacji, gdzie zatrzymany, posądzony o przynależność do $\mathrm{AK}^{42}$.

Warto zapoznać się z ustaleniami Grzegorza Motyki. We wrześniu 1944 r. Sowieci przeprowadzili wielkie obławy w rejonie Lidy, Naliboków i Wilejki. Według ich ocen zabili 89 osób, złapali 419 partyzantów i zatrzymali 20774 osoby, wśród których wykryto 682 „bandytów”, 306 współpracowników podziemia, 9666 uchylających się od służby wojskowej, kolejne 50 osób zabito ponoć w trakcie ucieczki ${ }^{43}$. Spróbujmy policzyć hipotetyczne Ofiary z ustaleń Motyki. Zabici według dokumentów to z pewnością 139 osób $(89+50=139)$. Prawie na pewno zabito tzw. „bandytów” (682 osoby), podobnie „partyzantów” - wszak to synonim „bandytów” (419 osób). Z kolei nie oszczędzono współpracowników podziemia (306 osób) i chyba rozprawiono się z uchylającymi się od służby wojskowej - wszak to dezerterzy, których w czasie wojny się zabija; może czasami zsyła do karnych kompanii, co na jedno wychodzi, ale to na ogół Polacy nie palili się do służby w Armii Czerwonej, więc wniosek tylko jeden - kolejna liczba 9666 do zabicia. Razem: 139+682+419+306+9666=11 212 Ofiar lub przy braku chęci do ułaskawień suma ta może osiągnąć niebotyczny wymiar $21282(89+419+20774=21282)$. Ja nazwałem to Obławą Nowogródzką i termin ten wprowadziłem do obiegu naukowego ${ }^{44}$.

Jeszcze przyjrzyjmy się danym $\mathrm{z}$ innego, już rosyjskiego wydawnictwa, ale powiązanego ze służbami specjalnymi. I tak według stanu na 14 października 1944 r. w zachodnich obwodach BSSR w związku z przeprowadzonymi operacjami likwidacji „białopolskich band” zabito 444 osoby, wzięto żywcem 927 bandytów

${ }^{41}$ N. Pietrow, Psy Stalina, s. 225-226.

42 Archiwum ZPOOA, kopia pisma FSB nr 10/A-R-1526 z 13 VI 2013 r.

43 G. Motyka, Na białych Polaków obława..., s. 155.

${ }^{44}$ K. Jasiewicz, Siedemdziesiata rocznica obławy augustowskiej: w poszukiwaniu genezy ostatniej zbrodni sowieckiej na obywatelach polskich w lipcu 1945 roku, w: W hołdzie ofiarom obławy augustowskiej z lipca 1945 roku, red. S. Wysocki, Suwałki 2015. 
i 9670 dezerterów z Amii Czerwonej ${ }^{45}$. Można przyjąć, że w tych liczbach nie musi mieścić się Obława Nowogródzka, była ona we wrześniu 1944 r. i przy ogromnej liczbie zatrzymanych wymagało sporo czasu, aby wszystkich dokładnie przefiltrować, zwłaszcza że filtracja zapewne posiadała ważne drugie dno. Pierwszym było sprawdzenie, kto jest kim, a drugim - wydobycie informacji o innych „bandytach” i „podejrzanych”.

W 1945 r. Sowieci przeprowadzili na Kresach Wschodnich łącznie 2609 operacji czekistowsko-wojskowych, z czego 13 dużych, obejmujących dwa-trzy obwody. Nie mamy nawet pojęcia, ile tysięcy nieznanych nam z imienia i nazwiska osób, b. obywateli II RP, leży gdzieś zakopanych, a upływ czasu i naturalne wymarcie ich rodzin skazują Ofiary na wieczne zapomnienie. Stwierdzenie, że Zielenin i Gorgonow oraz batalion SMIERSZ mają doświadczenie, jak widać miało swoje mocne podstawy faktograficzne.

Sięgnijmy ponownie do anonimowej relacji z Kadysza. Relacjonista podaje, że aresztowano wszystkich mężczyzn ze wsi. Zostali przewiezieni na Litwę i tam przebywali około tygodnia. Prawie wszystkich wypuścili. „Strach było pytać, gdzie ich przetrzymywali”. Nie jest jasne - przepadli bez wieści ci, co ukrywali się po lasach? W relacji zostały podane nazwiska mężczyzn przed trzydziestką z tejże wsi (Jan Łakiewicz, Władysław Promski, Bolesław Lis), którzy zaginęli bez wieści. Ich rodziny zostały wywiezione ${ }^{46}$. To analogia ze Zbrodnią Katyńską - tam też wywieziono rodziny zamordowanych w deportacji 13 kwietnia 1940 r. Taka była praktyka i tradycja systemu bolszewickiego.

Reasumując, wojska sowieckie w styczniu 1944 r. przekroczyły dawną granicę wschodnią II RP i szybko dotarły do historycznej krainy zwanej Rusią Czarną (obszar między Prypecią, Ptyczem i górnym Niemnem; a więc i Nowogródczyzna), który od północnego zachodu graniczy z Grodzieńszczyzną (ta ostatnia czasami, ale chyba w sposób nieuprawniony, bywa też zaliczana do Rusi Czarnej) ${ }^{47}$. Z pomocą wojska, wojsk NKWD i kontrwywiadu wojskowego SMIERSZ rozpoczęto na wielką skalę oczyszczanie tego terenu, który spłynął krwią. Obława Augustowska była ostatnią z wielkich operacji/,akcji kontrwywiadowczych”, a wspomniany w szyfrogramie Abakumowa „batalion wojsk Zarządu SMIERSZ 3 Frontu Białoruskiego”, zapewne składający się z około kilkuset czekistów, zajmował się „pomocnictwem” w mordowaniu. Z szyfrogramu wyłania się też prawdopodobny sposób zabijania - wedle technik katyńskich, bo z Moskwy przylatuje ekipa katów. Tu kłaniają się dane z operacji katyńskiej. Średnio taka ekipa zabójców składała się z kilku katów, $\mathrm{z}$ miejscowych dobierali sobie pomocników. Ich moce przerobowe wynosiły średnio 200 osób na noc ${ }^{48}$.

45 Органы государственной безопасности СССР в Великой Отечественной войне, т. 5, кн. 1: „Границы СССР восстановлены” (1 июля - 31 декабря 1944), Москва 2007, s. 458.

46 Relacja anonimowa z przebiegu Obławy Augustowskiej we wsi Kadysz na Grodzieńszczyźnie.

47 https://pl.wikipedia.org/Wiki/Ruś_Czarna (dostęp: 3.10.2018).

48 Zob. zeznania Tokariewa i Syromiatnikowa w: Katyń. Dokumenty zbrodni..., t. 2, s. 423 nn. 
Wydaje się także, że Sowieci musieli obok wcześniejszego rozpracowania wywiadowczego mieć swoje sposoby podczas filtracji. Może temu służył cykl śledczo-wydobywczy pięciodniowy. Bito zatrzymanych, aby się przyznali do bycia członkami AK lub wskazali podejrzane o to osoby. Wyraźnie widać inną technikę przetrzymywania aresztantów. Są w bardzo małych grupkach - po kilka-kilkanaście osób, bez prawa do korespondencji. Są zabijani na odludziu, choć zapewne - podobnie jak w trybie katyńskim - potrzebny jest jakiś budynek, choćby leśniczówka. Bo trzeba sprawdzić tożsamość przed egzekucją. Może czasami były to budynki odległego chutoru, skąd zwłoki wywożono samochodami w głąb lasu. Nie można wykluczyć, że zabijano nagie Ofiary, względnie po śmierci zdzierano odzież po to, by wykluczyć w przypadku wykrycia mogił jakąkolwiek identyfikację. Myślę też, że szczątki Ofiar Obławy Augustowskiej muszą być zakopane po stronie rosyjskiej, bo tam procedury ochrony takich grobów przed intruzami wydają się być skuteczne. Teraz, gdy mamy pewność, że Obławą była objęta część Litwy, nie licząc śledztw wobec osób przekazanych do dyspozycji organów NKWD-NKGB, i część Grodzieńszczyzny, to doskonałym miejscem - ze względów logistycznych - wydaje się zbieg granic Polski, Litwy i Białorusi, gdzieś w okolicach wsi Kalety, leśniczówki Giedź i Jeziora Szlamy. Wydaje się, iż Obława Augustowska składała się z kilku faz. Pierwsza, przypadająca na miesiące poprzedzające, polegała na zbieraniu przez agenturę i własną partyzantkę informacji o polskim podziemiu niepodległościowym. Być może do tej fazy można zaliczyć już aresztowania majowo-czerwcowe, począwszy od aresztowań podczas odpustu w Studziennicznej w Puszczy Augustowskiej. Faza druga główna, między 12 a 19 lipca, to operacja wojskowa z udziałem 62 Dywizji Wojsk Wewnętrznych NKWD, funkcjonariuszy SMIERSZ, miejscowego UB i MO. Faza trzecia - to proces aresztowań wtórnych, spowodowanych śledztwem wydobywczym poprzez tortury dalszych informacji o polskim podziemiu, trwa od 20-21 lipca do jesieni 1945 r.; na tę fazę przypadają egzekucje. Faza czwarta - od 1945/1946 r. do III RP, to ochrona tajemnicy zaginięcia i zacieranie śladów, być może przy pomocy rosyjskich służb i polskich potomków osób zamieszanych w Obławę Augustowską po stronie sprawców.

Obława to ostatni wielki mord na obywatelach obcego państwa dokonanych przez Rosję, spadkobierczynię tradycji bolszewicko-carskich, w czasach pokoju, po zakończeniu II wojny światowej. A zarazem pierwszy mord ZSRS/Rosji otwierający całą serię mordów/zbrodni na innych narodach, także w ramach imperium: od masowych gwałtów na Niemkach i samosądów na obywatelach b. III Rzeszy w sowieckiej strefie okupacyjnej w Niemczech, przez deportację Tatarów Krymskich, tłumienie Powstania Węgierskiego, Praską Wiosnę, po zbrodnie wojenne w Czeczenii, aneksję Krymu, Osetii, częściowo Donbasu i współczesne sponsorowanie ugrupowań terrorystycznych, anarchistycznych i lewackich, wywoływanie zamieszek i przewrotów, stymulowanie napływu uchodźców do Unii Europejskich w celu jej destabilizacji. Przyszłość w tej perspektywie wydaje się mało słoneczna. 


\section{The Augustów Roundup - current state of research, its circumstances and perspectives}

\section{Abstract}

In January 1944 the Soviet Army crossed the former eastern border of the Second Polish Republic. With the help of the army, military formations of NKVD and military counter-intelligence SMERSH, a large-scale cleansing of the held territories started. The Augustów Roundup was the last of the large "counter-intelligence actions” of the battalion of the SMERSH Directorate troops of the $3^{\text {rd }}$ Belorussian Front. It had all the hallmarks of the Katyń operation. A group, probably counting several hundred Chekists, was responsible for the physical elimination of the identified detainees. It seems that the Soviets must have had their own method of filtration in addition to a prior intelligence work. It might have been the 5-day cycle of interrogation. The detainees were beaten into the confession of being AK members or into indicating people suspected of it. A completely different technique of detention of the arrested can be observed. They were kept in small groups - a few-several persons without the right to correspondence. They were killed in the middle of nowhere, but probably, just like in the Katyń-mode, a building of some kind was necessary. The people might have been killed naked or were disrobed post-mortem to rule out identification in case the gravesite was found. Probably the remains of the victims of the Augustów Roundup are buried on the „Russian” side of the border. Now, when we are sure that the Roundup was also conducted in parts of Lithuania (not counting the investigations against the individuals placed at the disposal of NKVD-NKGB administration), as well as in a part of the Grodno region, the perfect place - from the logistic point of view - seems to be the intersection of the Polish, Lithuanian and Belorussian borders, somewhere in the vicinity of the village of Kalety, a rangers station of Giedź and the lake of Szlamy. The Augustów Roundup comprises several stages. The first one involved collecting information on Polish sovereignist underground by Soviet undercover agents and guerrillas. Perhaps, the May-June 1945 arrests might be included into this stage, starting with the arrests at the village fête in Studzienniczna in Augustów Forest. The second stage - between 12 and 19 July - was a military operation with the participation of the $62^{\text {nd }}$ Division of the Interior Army of the NKVD, SMERSH officers and the local UB (secret security) and MO (militia). The third phase was a process of secondary detentions caused by the investigation by tortures to extract further information on the Polish underground. It took place between 20-21 July and autumn 1945. At this stage there were also executions. The fourth phase - from 1945/1946 to the Third Polish Republic - a protecting of the secret of the dissapearance and covering the tracks, probably with the help of the Russian secret service and Polish descendants of the people involved in the Augustów Roundup on the side of the perpetrators.

\section{Августовская облава - состояние исследований, определяющие их факторы и перспективы}

\section{Аннотация}

В январе 1944 г. Советская армия перешла восточную границу 2-й Польской Республики. С помощью армии, войск НКВД и военной контрразведки СМЕРШ началась крупномасштабная зачистка занятой территории. Августовская облава была последней из больших «контрразведывательных акций» армейского батальона Управления СМЕРШ-а 3-го Белорусского фронта. У нее были все признаки схожие с Катыньской операцией. Группа, предположительно, состоящая из нескольких сот чекистов занималась ликвидацией определенных задержанных. Кажется, у советов должны были быть 
свои методы во время фильтрации, кроме заранее проведенной разведывательной разработки. Может быть для этого употреблялся пятидневный цикл допросов. Задержанных избивали, чтобы те признались в членстве в Армии Крайовой или указали на лица, подозреваемое в этом. Отчетливо видна другая техника передержки арестованных. Они в очень небольших группах - в несколько человек, без права на переписку. Их убивают на пустошах, хотя, предположительно - так же как и в Катыньском «режиме» - нужно какое-то здание. Нельзя исключить, что людей убивали голыми или после смерти с них срывали одежду, чтобы, в случае находки могил, исключить какую-либо идентификацию. Вероятно, останки жертв Августовской облавы покоятся на «российской» стороне границы. Сейчас, когда у нас уверенность в том, что облава обхватывала часть Литвы, не считая дел возбужденных против людей, переданных в распоряжение органов НКВД-НКГБ, а также часть Гродненщины, идеальным местом, в логистическом отношении, кажется стык границ Польши, Литвы и Беларуси, где-то в окрестностях деревни Калеты, лесничества Гедзь и озера Шлямы. Августовская облава состояла из нескольких этапов. Первый заключался в собрании агентурой и собственным партизанским движением информации о польском подполье защитников независимости. Может быть к этому этапу можно причислить уже майские-июньские аресты, начиная с арестов во время народного гулянья в Студщенничной в Августовской пуще. Второй этап - между 12 и 19 июля - это военная операция, в которой принимали участье 62-я дивизия внутренних войск НКВД, работники СМЕРШ-а, местного УБ (служба безопасности) и МО (милиция). Третий этап - это процесс вторичных арестов, вызванных следствием с пристрастием, добывающем очередную информацию о польском подполье, который продолжался с 20-21 июля до осени 1945 г. На этот этап приходятся казни. Четвертый этап - с 1945/1946 по времена тн. 3-й Польской Республики - защита тайны исчезновения и сокрытие следов, может быть с помощью российских служб и польских потомков людей, замешанных в Августовскую облаву на стороне виновников.

\section{Bibliografia}

Birstein V.J., SMIERSZ. Tajna broń Stalina. Sowiecki kontrwywiad wojskowy podczas II wojny światowej, Warszawa 2013.

Filipowicz M., Obława augustowska w lipcu 1945 r. w świetle zachowanych dokumentów, „Rocznik Augustowsko-Suwalski” 3, (2003).

Głowacki A., Sowieci wobec Polaków na ziemiach wschodnich II Rzeczypospolitej 1939-1941, Łódź 1998.

Jasiewicz K., Rola teorii, hipotez i spekulacji w wyjaśnianiu zbrodni katyńskiej. Rzecz o metodologii i metodyce badań, „Przegląd Historyczno-Wojskowy” 13 (64) (2012), nr 4 (242).

Jasiewicz K., Siedemdziesiąta rocznica obławy augustowskiej: w poszukiwaniu genezy ostatniej zbrodni sowieckiej na obywatelach polskich w lipcu 1945 roku, w: W hołdzie ofiarom obławy augustowskiej z lipca 1945 roku, red. S. Wysocki, Suwałki 2015.

Jasiewicz K., Zagłada polskich Kresów. Ziemiaństwo polskie na Kresach Pótnocno-Wschodnich Rzeczypospolitej pod okupacja sowiecka 1939-1941, Warszawa 1997.

Katyń. Dokumenty zbrodni, red. i oprac. nauk. W. Materski, N. Lebiediewa i in., t. 1: Jeńcy nie wypowiedzianej wojny, Warszawa 1995; t. 2: Zagłada, Warszawa 1998; t. 3: Losy ocalałych, Warszawa 2001; t. 4: Echa Katynia, Warszawa 2006.

Milewski J.J., Zaginieni w obławie augustowskiej - poszukiwania i pamięć, w: Obława Augustowska (lipiec 1945 r.), red. J.J. Milewski, A. Pyżewska, Białystok 2005.

Motyka G., Na białych Polaków obława. Wojska NKWD w walce z polskim podziemiem 19441953, Kraków 2014. 
Pietrow N., Psy Stalina, Warszawa 2012.

Pyżewska A., Komitet niosący nadzieję, w: Obława Augustowska (dod. do „Pamięć.pl”), [Warszawa, lipiec 2015].

Петров Н.В., По сценарию Сталина: роль органов НКВД-МГБ СССР в советизаиии стран Центральной и Восточной Европы. 1945-1953 гг., Москва 2011.

Krzysztof Jasiewicz, prof. dr hab., pracownik naukowy Instytutu Studiów Politycznych PAN. Zajmuje się badaniem historii Ziem Wschodnich RP pod okupacją sowiecką, w tym losami polskiego ziemiaństwa, sowieckimi warstwami przywódczymi, historią Żydów na Ziemiach Wschodnich, a także stosunkami polsko-żydowskimi w latach 1939-1941. Autor m.in.: Lista strat ziemiaństwa polskiego 1939-1956, Warszawa 1995; Zagłada polskich Kresów: ziemiaństwo polskie na Kresach Północno-Wschodnich Rzeczypospolitej pod okupacja sowiecka 1939-1941: studium z dziejów zagłady dawnego narodu politycznego, Warszawa 1997; Rzeczywistość sowiecka 1939-1941 w świadectwach polskich Żydów, Warszawa 2010 (kjasi@isppan.waw.pl).

Krzysztof Jasiewicz, Prof. Dr hab., a researcher at the Institute of Political Studies of the Polish Academy of Sciences. He studies the history of Eastern Territories of the Polish Republic under the Soviet occupation, including the fate of the Polish gentry, the Soviet leadership strata, history of the Jews in the Eastern Territories and also the Polish-Jewish relations in 1939-1941. He is the author of, i.a.: Lista strat ziemiaństwa polskiego 1939-1956, Warszawa 1995; Zagłada polskich Kresów: ziemiaństwo polskie na Kresach Pótnocno-Wschodnich Rzeczypospolitej pod okupacja sowiecka 1939-1941: studium z dziejów zagłady dawnego narodu politycznego, Warszawa 1997; Rzeczywistość sowiecka 1939-1941 w świadectwach polskich Żydów, Warszawa 2010 (kjasi@isppan.waw.pl). 